Provided by the author(s) and University of Galway in accordance with publisher policies. Please cite the published version when available.

\begin{tabular}{|c|c|}
\hline Title & $\begin{array}{l}\text { 'Homeliness meant having the fucking vacuum cleaner out': } \\
\text { the gendered labour of maintaining conference communities }\end{array}$ \\
\hline Author(s) & Burford, James; Bosanquet, Agnes; Smith, Jan \\
\hline $\begin{array}{c}\text { Publication } \\
\text { Date }\end{array}$ & $2019-10-24$ \\
\hline $\begin{array}{l}\text { Publication } \\
\text { Information }\end{array}$ & $\begin{array}{l}\text { Burford, James, Bosanquet, Agnes, \& Smith, Jan. (2019). } \\
\text { 'Homeliness meant having the fucking vacuum cleaner out': } \\
\text { the gendered labour of maintaining conference communities. } \\
\text { Gender and Education, 1-15. doi: } \\
10.1080 / 09540253.2019 .1680809\end{array}$ \\
\hline Publisher & Taylor \& Francis \\
\hline $\begin{array}{l}\text { Link to } \\
\text { publisher's } \\
\text { version }\end{array}$ & https://doi.org/10.1080/09540253.2019.1680809 \\
\hline Item record & http://hdl.handle.net/10379/15556 \\
\hline DOI & http://dx.doi.org/10.1080/09540253.2019.1680809 \\
\hline
\end{tabular}

Some rights reserved. For more information, please see the item record link above. 


\title{
'Homeliness meant having the fucking vacuum cleaner out': The gendered labour of maintaining conference communities
}

\author{
James Burford*a ${ }^{*}$ Agnes Bosanquet ${ }^{b}$, and Jan Smith ${ }^{c}$ \\ ${ }^{a}$ Research Education and Development Unit, Graduate Research School, La Trobe \\ University, Melbourne, Australia; ${ }^{b}$ Faculty of Human Sciences, Macquarie University, \\ Sydney, Australia; ' Independent Scholar, Durham, England
}

Corresponding author*

Dr James Burford

Research Education and Development Unit

Graduate Research School

La Trobe University

Australia

j.burford@latrobe.edu.au

\section{Acknowledgement}

The authors would like to thank Sandra Acker and Barbara Grant for their thoughtful feedback during the writing of this paper. We also acknowledge the contributions of co-researchers in the project A Decade of Dialogue: A cultural history of the International Academic Identities Conference 2008-2018, which is funded by the Research Institute for Higher Education (RIHE), Hiroshima University. The research team includes: Tai Peseta, Machi Sato, Catherine Manathunga, Jeanette Fyffe, Fiona Salisbury, Jan Smith, James Burford, and Agnes Bosanquet. 


\title{
'Homeliness meant having the fucking vacuum cleaner out': The gendered labour of maintaining conference communities
}

\author{
Abstract: This article extends examinations of the gendered nature of care \\ and service in academia, with a particular focus on the labour of \\ maintaining conference communities. Utilising empirical data from a \\ cultural history of the International Academic Identities Conference \\ (2008-2018), we draw on interviews with thirty-two conference \\ organisers, keynotes and participants to explore the gendered dynamics of \\ reproducing conference communities. While some participants \\ experienced exclusions, most participants described a conference that felt \\ caring, welcoming and like 'home'. Following this discussion, we \\ interrogate the idea of the conference as 'home', asking questions about \\ the gendered division of 'academic housekeeping' practices that underpin \\ such home-making. Engaging with feminist theorising of emotional \\ labour, we argue that academic women undertook significant, and often \\ hidden, care and service labour to maintain a homely conference \\ community.
}

Conferences are complex events that shape the working lives of academics. Sometimes they begin as an idea pencilled into a diary, a vague commitment to submit something, or time spent waiting for an email. Other times they press upon our attention and require our bodies to work: to submit an abstract urgently, to weave our way through airport queues, and to travel across time zones as we seek possibilities for connection, learning and collaboration. For participants, conferences may represent a quarantined space of withdrawal from the ordinary, a place of retreat or 'escape from work or domestic routines' (Hart, 1984, p 125). They may also prompt significant interruptions that impact participants' (and their loved ones') lives. For organisers, this impact is intensified, with the work that underpins the production of a conference involving a great deal of hidden labour. 
Given the ubiquitous nature of conferences in academic life, it is surprising that these spaces of learning and networking have been infrequently subject to analysis by educational researchers. Much of the discussion is dispersed across a variety of disciplines including geography (Derudder and Lui, 2016), psychology (Carpay, 2001) and sociology (Dubrow et al., 2018). Occasional accounts have emerged from educational researchers (e.g. Elton, 1983; Hart, 1984; Lawn, 2015; Skelton, 1997; Walford, 2011), but only recently have conferences been recognised as an important locus for higher education research (Henderson, 2015; Jackson, 2017). While there has been attention to gendered forms of exclusion in educational research communities (Henderson, 2017), there has been limited theoretical and empirical attention given to the labour of producing and caring for conference communities.

Given our knowledge of the gendered distribution of service work and community building in academia (Toffoletti and Starr, 2016; Heijstra, Steinthordottir and Einarsdottir, 2017), we believe it is important that conference organising is subject to critical interrogation. To do so we draw on interviews with thirty-two conference organisers, keynote speakers and participants from the International Academic Identities Conference (2008-2018). Over the last decade, this conference has been held in five countries around the world. It is independent (not affiliated with a particular organisation or institution), small in scale (with 80-100 delegates) and hosted within university spaces. Women's participation has far outnumbered men's as convenors, conference committee members, keynote speakers and delegates. At one conference, all of the keynote speakers were women. Given these characteristics, these conferences ought to be considered an exception rather than a norm in terms of academic gatherings. Overall, the conferences focus on the research preoccupations of academic identity scholars as they contend with the demands of shifting ideas and contexts in higher 
education. The intellectual contributions emerging from this conference have been discussed previously (Smith, 2010; Smith et al, 2016; Grant et al, 2014; Peseta, Barrie and McLean, 2017); however, its internal processes have not yet been subject to investigation.

Our title is taken from the words of one conference organiser, whose narrative account forms an important part of our discussion. As we will outline, the majority of participants describe a conference that feels caring, welcoming and home-like. It is our view that the gendered labour of producing 'homeliness' through 'academic housekeeping' practices warrants further interrogation. Therefore, this article seeks to answer the following question: if a conference is described by its community as feeling like home, who does the housework?

\section{Conferences as gendered spaces}

Academic conferences have been characterised in myriad ways: as blurry spaces between the professional and personal (Jackson, 2017); as collectives where learning happens (Jacobs and McFarlane, 2005; Burford, Henderson and Pausé, 2018); as spaces where postgraduate students are socialised into a discipline (Hickson, 2006; Mantai, 2017); and as locations where communities are built and maintained (Bell, 1993). Conferences are sites of 'social, emotional and intellectual activity'; and as Henderson (2018) notes, missing any of these dimensions would be to 'conduct an incomplete analysis' (p 915). Rather than spaces removed from the conventions of academe, conferences are 'microcosms or reproductions of universities' (Henderson, 2018, p 39) or 'temporary institutions' (Lewis, 2013, p 881). That is, they are relational (Lewis, 2013) and ought to be seen as 'site[s] where power relations are exercised' (Blumen and Bar-Gal, 2006, p 341). At conferences, participants experience inclusion and exclusion based on social markers of difference including gender (Jackson, 2017), race (King et 
al., 2018), sexuality (Burford, 2017), disability (Hodge, 2014) and class (Stanley, 1995).

Feminist researchers have focussed on the gendering of academic conferences, noting that 'men and women are encountered and treated in different ways' (Jackson, 2017, p 5; see also Mair and Frew, 2016). Before conferences begin, women's participation is disproportionately impacted by other responsibilities such as childcare (Henderson, 2017, 2018). At conferences, there are often differences in the visibility of academic men and women. Building on Isbell et. al's (2012) study which found men requested talks over poster presentations, Jones and colleagues (2014) found women tend to select shorter speaking slots. A recent study offers evidence that men ask more questions at conferences (Hinsley et al, 2017). Gender differences are similarly evident in conference organisation. Eden (2016) found that women are often invited to greet participants but less likely to chair or present, supporting Blumen and Bar-Gal's (2006) finding that women tend to be involved in the 'less prestigious' aspects of conferences (p 341).

In this article we contend that conference community building be recognised as a form of gendered academic labour. This inquiry builds on decades of gender studies scholarship investigating conferences, which has considered not only feminist and women's studies conferences (Bowles, 2002), but also feminist conference pedagogies and organising strategies (Saul, 1992; Bell, 1993; Pereira, 2012). We contribute to this body of work by examining how a particular conference is described by its participants as 'warm' and 'homely', and identifying the care and labour that goes in to the production of such an experience. We seek to determine whether conference practices are consistent with the gendered distribution of academic work more broadly, where women undertake significant service responsibilities (Toffoletti and Starr, 2016; 
Heijstra, Steinthordottir and Einarsdottir, 2017), and women's leadership is recognised in 'soft' domains such as maintaining group cohesion, wellbeing and care (Eden, 2016).

\section{Gendered positioning at academic conferences}

Acker and Armenti (2004) ask feminist scholars to investigate "what subject positions are available to women (in higher education, as elsewhere) and how discourses such as those about masculinity and femininity...organi[se] our thinking' (p 6). Such a project necessitates:

bringing to light the normative frames within which people actually carry on their lives, thinking, feeling, acting, and perceiving — against standards of correctness. In short, positioning theory looks at what a person "may do and may not do" (Harré, Moghaddam, Cairnie, Rothbart and Sabat, 2009, p 9).

Searching for subject positions means identifying patterns (implicit or explicit) by which people act. For example, subjects might be strong or weak, obedient or subversive, spectacular or ordinary. Individuals can be positioned by others (interpretive positioning) or by themselves (reflexive positioning). It is, however, important to point out that there is no single 'true' interpretation of a subject's position.

In a conference research context, one example of positioning analysis is Jackson's (2017) study on the emotional labour undertaken by women at academic conferences. Jackson (2017) draws on some well-known positions identified by feminist scholars, such as Hochschild's (1983) identification of the sexy girlfriend and supportive mother as two prominent positions occupied by women flight attendants. In these two stances, women flight attendants perform emotional labour by absorbing the negative attitudes of customers and offering an outward expression of calm and cheerfulness. Both of these positions take on service scripts, with the sexy girlfriend using sex appeal to 
achieve the cooperation of male customers, and the supportive mother emphasising nurturing and sympathy. Drawing on personal experiences and social media representations, Jackson (2017) speculates that these two prominent postures might also help organise our thinking the approaches academic women take at conferences. She also identifies two other prominent positions available for junior academic women, the sunny daughter (who is expected to appreciatively listen to older academic men) and the little sister (who is expected to defer to her male colleagues). Arguably, the four subject positions that Jackson (2017) identifies configure women's agency as dependent. Here women are positioned as mothers, daughters, girlfriends and sisters - always defined in relation to someone else, in comparison to men who are defined as autonomous and individual agents. Jackson's (2017) four positions are also linked to 'caring scripts', a term Acker and Feuerverger (1996) use to describe the compassion and caring expected of women in traditionally feminised occupations such as teaching. However, Jackson (2017) also identifies positions outside of this logic. For example, her fifth subject position is the ungirly woman (not recognisable as normatively heterosexual or feminine). This position is not defined in relation to men, but instead in relation to heteronormativity. She may not be drawn in to expectations to care, but may be subject to teasing and harassment due to her failure to reproduce the status quo. Jackson's fifth position is closer to Ahmed's (2010) theorisations of the unhappy housewife and feminist killjoy, who also go off-script and resist expectations to 'put on a happy face for the benefit of the larger group' ( $p$ 3). Ahmed refers to these two positions as 'affect aliens', people who are caught in 'conflicting concerns with self and other' (p 4).

In this paper we extend Jackson's (2017) thinking on the supportive mother at conferences, identifying how this position was occupied by conveners in our study, and the kind of affects such a position generated. Additionally, we identify an associated 
position of the good housekeeper as another prominent posture that academic women organising the conference occupied. In thinking with these two positions (supportive mother and good housekeeper) it is our goal to extend scholarship that has demonstrated the greater responsibilities that women take 'for the nurturing and housekeeping side of academic life' (Acker and Feuerverger, 1996, p 401; see also Lynch, 2010; Guarino and Border, 2017). Often women undertake duties that are 'time consuming and undervalued, but nevertheless crucial for the continuity of the academic institution' (Heijstra et al., 2017, p 765). These contributions can be seen to import gendered roles from the domestic sphere where care and housekeeping are conflated and 'women's time is... characteristically others' time' (Rafnsdottir and Heijstra, 2013, p 285). The idea of 'academic housework' and subject positions such as the supportive mother and good housekeeper enable us to explore the gendered dimensions of caring and service work undertaken to keep conference communities functioning. As feminist scholars, we have a complex understanding of care and its costs. Thinking about Ahmed's (2010) 'unhappy housewife' in the context of academic housekeeping helps us to ask difficult questions. When should care be re-negotiated or declined? How do we know when we are 'caring too much'? Where should boundaries be drawn? And particular to the narrative we explore later, when might we live with an unclean floor?

\section{Narratives of conference experience}

We have explored a rich data set for stories that illustrate the welcoming and intimate space of a particular conference series, and the labour of care that underpins the maintenance of its community. Conferences here are understood as both formalwithin the academic programme — and peripheral or social spaces (Henderson, 2015), where academic identities are performed, formed and reformed. Thirty-two narrative 
interviews with convenors, keynote speakers, and delegates (of whom twenty-eight are women) inform the analysis. Eight researchers in a conference cultural history research project conducted interviews, either face-to-face or via video call, and recordings were transcribed for analysis.

We asked interviewees to recount stories to get a sense of their 'purposeful engagement' (Polkinghorne, 1995, p 5) in the conference community. The public nature of conference contributions, multiple attendances and varied roles gave rise to important ethical questions in both generating and interpreting our data. Each narrative stands as its own account of the conference as a way to "represent the uniqueness, the "otherness" of individuals into the structures, organisations, processes, practices through which everyday life can be constituted' (Schostak, 2006, pp 134-5). We acknowledge multiple viewpoints whilst also benefiting from our own 'insider' status in analysis.

To mitigate potential risks, our participants could choose how their information (e.g. their name, audio-recordings, extracts and photographs) is used in research publications. Critics often suggest that the restricted volume of narrative data that can be presented in a paper gives a limited account or is prone to 'cherry-picking'. This is a valid observation, given that we have data that we do not have consent to use (for instance, when interviewees asked us not to include a specific example, or where information might identify an individual who did not consent to be identified), but Polkinghorne (1995) counters that the reader judges narrative analysis on the plausibility of the story told. Our analysis, as Polkinghorne (1995, p 16) suggests, 'attends to the temporal and unfolding dimension' of conference organisation and participation related to key concepts such as academic housekeeping, emotional labour and gendered notions of care. While only limited narrativisation is presented due to 
space constraints and potential for identification, convenors, keynote speakers and delegates (including a sub-category of doctoral students) are represented.

We categorise our narratives as 'experience-centred' (Squire, 2008, p 41). The interview schedule sought to ascertain the identities and affiliations that participants brought with them, and reflections on what they thought and did following conference attendance. As interviews took place after attendance, sometimes years later, they 'represent' (Squire, 2008, p 42) conference experiences and subsequent reflections, but nonetheless exhibit the bounded temporality necessary for narrative analysis (Polkinghorne, 1995).

For the purposes of analysis, each transcript was allocated to an author who had not conducted the interview. All transcripts were analysed and coded against themes of care, community, home and labour as early readings suggested these ideas were important in the sense of Polkinghorne's $(1995, \mathrm{p} 9)$ 'paradigmatic cognition'. After circulating our initial attempts at analysis, it became clear that we could undertake both 'analysis of narratives' which would aim to categorise, and 'narrative analysis' that would foreground the stories of individuals (Polkinghorne, 1995).

\section{The conference as 'home'}

Recurring across the thirty-two interview transcripts are the words 'welcoming', 'warm' and 'home' or 'homely'. As one delegate shares, the Academic Identities Conference was 'one of the first [times] when I really felt at home at a conference' (Lyle, Delegate). It is described by participants as having 'heart' (Rosemary, Delegate); 'the best conference I've ever been to ... It is my home conference. You know, it is the conference that I want to go to every two years' (Margie, Delegate). Others describe it offering an experience of 'genuine support and warmth' (Jessica, Keynote), even for 
newcomers: 'Even though I was only there once, it definitely felt like a home to me, in many ways' (Maria, Keynote) and 'I found it very kind of homely, in a way, very welcoming in a way that you don't always get at conferences' (Robert, Delegate). The welcome was identified as a crucial aspect of home-making: 'The hearth was warm' (Juliet, Multiple roles). One delegate described returning for a subsequent conference:

As I mentioned before ... feeling at home .. I felt much more at home in the conference space because I felt comfortable to talk to other people ... That made me feel much more part of a scholarly community which I found really positive, as if there's now a conversation that you can talk into. It's taken me a while to find places where I can do that and feel comfortable ... It was quite a welcoming space for that. (Lyle, Delegate).

A keynote speaker describes the 'sociability' of the conference: 'being surrounded by 'like-minded people ... intellectual peers ... a community of critical scholars' (Claire, Keynote). Participants describe 'warm personal touches' (Jessica, Keynote); the generosity of keynote speakers, and audiences 'learning from each other' (Lyle, Delegate). A keynote speaker describes feeling 'very much at home, very much loved [and] very much supported ... as a person, but also intellectually' by the organisers (Maria, Keynote). Participants describe a sense of belonging to a place where they 'fit in' and can be themselves, in contrast to other conferences: 'Being in another place, out of place, out of your own place, that is really a feature of conferences ... when you ... go to a conference that's not home for you' (Sara, Keynote). While other conferences 'can get a bit like a kind of a production line' (Lyle, Delegate), the Academic Identities Conference was described as offering 'a contrast with the bigger conferences ... that are held in hotels, that are so not homely ${ }^{1}$... They're held in huge, impersonal spaces'

\footnotetext{
${ }^{1}$ In British English the term 'homely' can refer to cosy and comfortable surroundings like what might be found in one's home. This is different to the North American usage which is used to describe an unattractive person.
} 
(Juliet, Multiple roles).

For those who are 'at home' in the conference space, and have a secure attachment to their academic identity, the intimacy of the conference was welcome:

I enjoyed being part of the community ... that whole on-the-ground, catching up with old friends, crying over our academic lives in the corner occasionally ... It's the kind of place where both ... the presentations and the sub-textual agenda of ... what you're talking about are actually intermingled ... The possibilities of our private lives are connected to the possibilities of our academic lives in really important ways. So I love that. It's a very special thing. (Juliet, Multiple roles)

The boundaries between public and private lives are permeable at conferences. One participant described feeling 'apprehensive about work and home overlapping at the conference' because she was sharing accommodation with colleagues: 'Normally I try and protect home time at a conference. Sort of my down time. [But] I really loved sharing with my colleagues, I have to say, and it was very nice' (Rosemary, Delegate).

For others, the conference was less welcoming. One respondent described it as 'a bit of an in group' (Joanne, Delegate). Another said: 'I felt a wee bit on the outside' (Katya, Delegate). Of note is the way in which critical discussions of the context of academic work resonate differently for audience members, for a variety of reasons including whether they are secure or established in academia. A delegate who was a $\mathrm{PhD}$ candidate at the time, and hoping to become an academic, spoke of her response to a keynote presentation:

[The keynote] spoke about people who left academia and it turned out that they were much happier ... And that was quite shattering, shocking ... It was really discouraging ... the stories that these people reported, the feelings they had, those strong emotions and physical [impacts]. They were sick, they were stressed, they weren't happy ... I think the whole conference was a warning to me ... It was 
almost like being hit with a hammer ... I was really shattered. I must have even cried a little ... walking back to the train ... realising that as a woman, as a young academic, as a woman, as a new mum, that all these factors would make [academia] really hard for me (Violet, PhD Student).

This violent imagery of being 'shattered' by a 'hammer' is in stark contrast to the descriptions of a welcoming home experienced by others. Two participants recall crying at the conference; one finds solace in the conference community, the other feels isolated. Challenging presentations shape participants' experiences and, if the conference home has a mat, it clearly signals 'welcome' to some delegates more than others. Another participant raised a concern about the inclusivity of the conference for people with disabilities, and the prohibitive costs of attendance for members of disadvantaged groups (Laura, Delegate). Others shared concerns that the conference was not as ethnically diverse as it could be:

\footnotetext{
It was much warmer than a lot of conferences I go to but I was a little bit disappointed by the lack of other brown people ... Not because I thought the conference had done a really bad job of attracting them but because we have so much to offer this space ... I kind of went 'Oh, no brown faces in here.' There were other diverse faces in the room but being brown wasn't one of them (Jessica, Keynote).
}

The intersections of gender and race are evident in this narrative account offered by a Māori woman academic. She saw her role as 'somebody from that home place' to 'welcome people into that space ... ground them in the knowledge of who the people are from there, and what their issues are' (Jessica, Keynote). Given Aoteaora New Zealand's history of colonial settlement and indigenous displacement, it is important to consider what it means that this delegate does not see people who look like her. She is explicit: 'This can be a pretty uncomfortable and unhomely space if you are a first generation university student or a student who comes in from a diverse kind of cultural 
background, whatever that may be, this place can be pretty unhospitable, certainly unhomely' (Jessica, Keynote). In post-colonial contexts in particular, homeliness is a troubled notion and thoughts about who does not feel 'at home' in a conference about academic identities warrant further contemplation for this conference community (Manathunga, 2007).

\section{Who keeps house?}

While reading the transcripts we became attuned to the labours that underpinned the production of homeliness at this conference. We focus our attention on the care work undertaken by convenors, whilst acknowledging that care is distributed across the conference community. Participants care for each other in myriad ways; however, what stood out in the data was the role that conference organisers played in creating this homely and welcoming space. Convenors, and other members of the organising team, described their duties as a 'labour of love' involving a great deal of 'hidden work' (Bex, Multiple roles). This included descriptions similar to domestic labour:

I was really busy during the conference running around trying to be helpful, and so it was actually quite a blur and I felt quite numb from the whole conference ... and all of those hosting kind of things ... like making sure that the accommodation was .... hospitable .... I remember when ....somebody ripped their pants open and they asked me to find a safety pin ... I was running around, where are taxis and all of that kind of micro-stuff of making sure that everyone's feeling okay and doing okay. (Rory, PhD student)

Here the work of a member of the organising committee, in this case a queer man, is framed as care-full: 'hosting' and 'trying to be helpful'. The organiser expresses care by ensuring that lodgings are 'hospitable', sourcing transport and fixing clothing. Checking that everyone is 'feeling okay and doing okay' is minimised as 'micro-stuff', presumably in contrast to the macro-stuff of participating in the 
intellectual life of the conference. Tracking the body of the organiser, we notice that he is running twice in the narrative. This breathless embodied experience leaves him feeling blurred and numb. That conference organising involves taking care of other people's bodies was echoed by a convenor:

It's probably easiest just to say I've got a very blurred memory ... You're running around like a headless chicken as organiser [dealing with] any little hiccup that happens ... Somebody turned up on the morning and they'd laddered their stockings so I had to go and find a new pair of stockings for them (Bex, Multiple roles).

Again, we see a care-giving role where hiccups are dealt with, and clothes are fixed. Similarly, this convenor describes running and feeling blurred. Her body is configured as headless, lacking memories of the event, rushing to find stockings and manage other people's small emergencies.

As these accounts suggest, taking responsibility for others comes at a price. One organiser said: 'You've got so much going on in your brain when you're trying to organise an event like that to give everybody else a good time, that you make your own life a misery ... The overwhelming memory is that everybody else has a good time and I had a miserable one' (Bex, Multiple roles). She contrasted her experience of organising with being a delegate:

Absolutely loving it. Really enjoying it, really feeling able to participate because you're not waiting for the coffee break so you can run away and deal with this email and print copies of people's handouts because their bag got lost on the flight ... You don't have any of that ... None of the pressure ... It's someone else's problem to make this work. I can choose what to go to. I don't have to chair the session that nobody else wants to chair ... Loving it, loving it, absolutely loving it (Bex, Multiple roles).

As a delegate, she delights in the freedom to participate. Yet as an organiser her extract 
is full of verbs that describe activity: she is waiting, dealing, printing and chairing. Like other organisers, she is 'running' to deal with the 'pressure' of emails, handouts, and lost bags. Another conference organiser described a similar gap between the experience she was creating for others, and her own feelings:

I felt very out of place, very alone and unstable ... I've got a bodily memory of organising that conference ... Actually, I just have to think about it and ... I feel stressed ... On the other hand the conference was quite joyful .... [I remember] my pleasure in the event itself, even though I experienced it with this level ... of preoccupation and worrying what the fuck was going to happen next (Juliet, Multiple roles).

In the remainder of this article we offer an extended narrative account from this convenor which illustrates constrained and contested subject positions. The title of this paper is taken from her words, which reflect the gendered labour of creating a homely and welcoming conference space:

On the very first day of that conference, I turned up and the main room we were going to be having our refreshments was really unclean ... Luckily I had my vacuum cleaner. I'd had this terrible feeling. So on the first morning of the conference I was in here at sparrow's [early] with a vacuum cleaner, trying to clean the rooms and feeling very shaky about it because there was so much to do ... It was quite homely ... I remember the homeliness of [the previous conference] ... I like the homeliness. And so one of the things I wanted to do with the conference here was to also have it in a workplace ... in an academic space ... but also have a kind of homeliness in the sense of the relationships ...... I think there's a politics, too, of conferences ... It's still a kind of performance. Homeliness is still a performance, a performance of home, right? But I think it's more welcoming ... On the other hand, the homeliness meant, for me at least, having the fucking vacuum cleaner out (Juliet, Multiple roles).

In response, the interviewer asked: 'So the homeliness also entailed a lot of domestic labour?' The organiser responded: 
A lot of domestic labour. All the way, actually, domestic labour. Yeah. It was kind of exhausting ... I had one of the keynotes staying in my home as well, so that's another aspect of domestic labour ... There were bodies there, bodies and people who need[ed] stuff. I remember [another speaker] on the morning of her keynote, because I think the heating mustn't have been working. In these buildings, the heating is really unreliable ... She was wearing, in June in [the southern hemisphere], this little polyester shirt. And she was waiting for her keynote to start in the atrium and she just began to shake with the cold. What we needed then was a hot water bottle down her jumper ... That was one of the little moments that ... would not have been homely in any sense whatsoever. For her, coming to [the southern hemisphere] in the winter is a really un-homely experience because we run such cold houses and institutions (Juliet, Multiple roles).

What sense can we make of this account? A conference organiser aspires to create a 'homely' conference in her academic workplace. She positions this effort as a political practice. Transforming academic institutions into welcoming and hospitable spaces is connected to the intellectual work of a conference series that is focused on the shifting identities of academics and deteriorating conditions of academic labour. Despite securing institutional support, the convenor has a 'terrible feeling' that the conference venue will not be clean. She arrives early ('at sparrow's fart') with her vacuum cleaner from home and, shakily, cleans before the delegates assemble. Starting work early is a welldocumented strategy; in 'Sleepless in academia', Acker and Armenti (2004) found working in the early hours enabled academic mothers to manage workloads, as did Fothergill and Feltey (2003) in a study of mothers on the tenure track entitled 'I've worked very hard and slept very little. While these studies refer specifically to the work practices of academic mothers, the gendered division of academic housekeeping wakes many women in the early hours. 
Feminist scholarship, including the work of Ahmed (2010) and Jackson (2017) has taught us that the supportive mother and good housekeeper are distinct roles. Our intention is not to conflate these, and we note how problematic it is to assume alliances between these subject positions. In other words, the good housekeeper is not necessarily a mother and a mother is not necessarily a good housekeeper.little'. Arguably, the vacuum in this extract signifies the work of the good housekeeper who labours to keep the floor clean and the 'hearth' warm. ${ }^{2}$ In our example, the conference organiser is not only undertaking 'domestic labour', she is surrounded by 'bodies who need stuff'. We might interpret this affective performance through the lens of the 'supportive mother' who addresses the 'unhomely' experience of the 'cold institution'. The care labour of attending to the physical needs of participants (warmth, appropriate clothing and shelter) are gendered performances that echo the subject position of 'supportive mother' identified by Jackson (2017) in relation to academic conferences. In a conference where participants repeatedly describe a sense of homeliness, and where almost all convenors have been women, the gendering of this home-making performance merits attention. By taking up the associated positions of the supportive mother and/or good housekeeper at conferences, convenors, in addition to intellectual and scholarly leadership, undertake housekeeping, time-keeping, hostessing, care-giving, crisis management and technical support. Responsibility is usually distributed across a team of organisers and support staff, overseen by the conference convenor, whose work is 'instantly interruptible', to use a phrase from Stadlen (2004) to describe the work of mothers. This care-taking and housekeeping can come at the expense of the conveners' wellbeing, as in the case of Juliet above. While Juliet performs the role of the good housekeeper by ensuring the

\footnotetext{
${ }^{2}$ We might also pay greater attention to the language of 'housekeeping' at conferences. This is often a specific speaking slot during plenary sessions where organisational details about scheduling, where to access information, amenities and catering are shared.
} 
venue is tidy, she also refers to her device as the 'fucking vacuum cleaner', suggesting that this performance plays out in a contested and affectively complex way. Two organisers use the word 'blur' to describe their memory of the conference, and others describe feeling miserable, numb, unstable and alone, and recall the exhaustion they feel post-event. Clearly, the outward performance of warmth and homeliness comes at a cost for some in the conference community.

As participants and organisers of the Academic Identities Conference ourselves (one author has convened the conference, the others have been members of organising committees), we have enjoyed the warmth of the conference and the feeling of homeliness. Our goal is to draw attention to this affective performativity as labour. How as a conference community can we ensure that the care practices underpinning a warm conference are given due recognition and support? While there are rituals at the conference where thanks are given and small gifts are exchanged, we wonder whether this is sufficient recognition of the labour that has been undertaken. Equally, in drawing attention to how the labour of producing conferences is distributed we would like to be clear that our preferred solution is not to shift this labour onto students (or others). While this might relieve convenors and others in the organising team, it may equally serve to reproduce existing university power hierarchies. More experimental solutions are required to re-frame how the conference thinks of its home, how participants understand their own relation to it, and to divvy up the chores that keep it functioning.

\section{Conclusion}

Drawing on interviews with conference organisers, keynotes and participants from a cultural history of the International Academic Identities Conference (2008-2018), we have surfaced accounts of caring and being cared for, the cultivation of a homely and welcoming conference space, and moments where community and care appear to lapse. 
We have considered the ways in which 'academic housekeeping' practices underpin the creation of warm and homely spaces. While this was a distributed phenomenon, and called on the labours of the entire conference community in different ways, it relied on the particular and detailed work of conference convenors. Academic women conference convenors interviewed in this study spoke of a number of 'domestic' acts such as vacuuming, providing hospitality and taking care of the physical bodies of participants. While essential to the production of warmth and homeliness, in an academic context these acts are hidden care and emotional labour that contrast with the public role of the conference convenor as intellectual leader.

Our article raises questions about the gendered performativity of academic housekeeping, and extends Jackson's (2017) thinking on the subject position of the 'supportive mother' to suggest that 'good housekeeper' is another position that convenors may occupy (Harré, Moghaddam, Cairnie, Rothbart and Sabat, 2009). Academic housekeeping is under-recognised and underappreciated. Convenors in our study were stressed by the obligations of care for their conference community. The gendered performativity of this work is clear; indeed, these narratives might be read quite differently if an academic man described stuffing a hot water bottle down a keynote speaker's shirt or locating a pair of stockings. This finding fleshes out a wider 'gendered care ecology' in relation to conferences and expands our understandings of how academic women's experiences of conferences are interwoven with care in multiple and complex ways.

It is important here to remember that these findings relate to a small and particular conference. It is not our intention to suggest that these findings are generalisable to bigger conferences across disciplinary areas, which may have professional staff undertaking organisational work and graduate students volunteering 
on reception tables and so forth. On the other hand, this conference may bear more resemblance to small-scale conferences or conference-like gatherings that academics often coordinate in their institutions (workshops, day events, seminar series). It may be that some of these events have similarities to the conference considered in this paper.

A question remains: why this desire to create a spick and span, intimate conference? This may highlight the specific nature of the relatively small conference from which our data is drawn; however, participants in this study are attuned to cultural and institutional politics, demonstrate an attentiveness to rituals and customs of welcoming, and respond to feelings of unhomeliness in universities and academic work more broadly. The Academic Identities Conference is constituted as a space to resist the dominant subject positions imposed by care-less institutions (Lynch, 2010) yet simultaneously imposes under-recognised care responsibilities upon its largely women organisers. So, even this conference that purports to critically explore academic identity is not immune from reproducing wider gendered dynamics of academic labour.

\section{References}

Acker, S. and Armenti, C. 2004. "Sleepless in academia". Gender and Education, 16 (1): 3-24. doi:10.1080/0954025032000170309.

Acker, S. and Feuerverger, G. 1996. "Doing good and feeling bad: The work of women university teachers". Cambridge Journal of Education, 26 (3): 401-422. doi:10.1080/0305764960260309.

Ahmed, S. 2010. The Promise of Happiness. Durham, NC: Duke University Press.

Bell, L. 1993. "Hearing all our voices: applications of feminist pedagogy to conferences, speeches, and panel presentations”. Women's Studies Quarterly, 21 (3-4): 107-113.

Blumen, O. and Bar-Gal, Y. 2006. "The academic conference and the status of women: The annual meetings of the Israeli Geographical Society". The Professional Geographer, 58: 341-355. doi:10.1111/j.1467-9272.2006.00572.x. 
Bowles, G. 2002. "Putting our heads together: Some personal recollections of NWSA national conventions 1979-1983”. NWSA Journal, 14(1): 124-133.

Burford, J. 2017, February 27. "Sex and the academic conference.” [Blog post] Retrieved from https://conferenceinference.wordpress.com/2017/02/27/sex-andthe-academic-conference/

Burford, J., Henderson, E. F., and Pausé, C. 2018. "Enlarging conference learning: At the crossroads of fat studies and conference pedagogies." Fat Studies, 7(1): 6980. doi:10.1080/21604851.2017.1360666.

Carpay, J. 2001. "A conference that couldn't take place." Mind, Culture, and Activity, 8(3): 268-271. doi:10.1207/S15327884MCA0803_5.

Derudder, B. and Liu, X. 2016. "How international is the Annual Meeting of the Association of American Geographers? A social network analysis perspective." Environment and Planning A, 48(2): 309-329. doi:10.1177/0308518X15611892.

Dubrow, J.K., Kolczynska, M., Slomczynski, K.M. and Tomescu-Dubrow, I. 2018. "Sociologists everywhere: Country representation in conferences hosted by the International Sociological Association, 1990-2012”. Current Sociology, 66(3): 466-489. doi:10.1177/0011392115590612.

Eden, D. 2016. “Women's participation in academic conferences in Israel.” Journal of Higher Education Policy and Management, 38(4): 406-421. doi:

Elton, L. 1983. “Conferences: Making a good thing rather better?” British Journal of Educational Technology, 14(3): 200-212. doi:10.1080/1360080X.2016.1181887.

Fothergill, A. and Feltey, K. 2003. "'I've worked very hard and slept very little': mothers on the tenure track in academia". Journal of the Association for Research on Mothering, 5(2): 7-19.

Grant, B., Burford, J., Bosanquet, A. and Loads, D. 2014. “Of zombies, monsters and song: The third academic identities conference". Teaching in Higher Education, 19(3): 315-321. doi:10.1080/13562517.2013.860113.

Guarino, C.M. and Border, V.M.H. 2017. "Faculty service loads and gender: are women taking care of the academic family?" Research in Higher Education, 58: 672694. doi: 10.1007/s11162-017-9454-2.

Harre, R. Moghaddam, F. Cairnie, T. Rothbart, D. and Sabat, S. 2009. "Recent advances in positioning theory". Theory and Psychology, 19(1): 5-31. doi: 
Hart, A. 1984. "The culture of the conference". Innovations in Education and Training International, 21(2): 121-129. doi:10.1177/0959354308101417.

Heijstra, T.M., Steinthorsdottir, F.S. and Einarsdottir, T. 2017. "Academic career making and the double-edged role of academic housework". Gender and Education, 29(6): 764-780. doi:10.1080/09540253.2016.1171825.

Henderson, E.F. 2015. “Academic conferences: Representative and resistant sites for higher education research". Higher Education Research and Development, 34(5): 914-925. doi:10.1080/07294360.2015.1011093.

Henderson, E. F. 2017. “Caring while conferencing: The 'In Two Places at Once' research project". Feminist and Women's Studies Association (UK and Ireland) Newsletter, 68, June, 11-12.

Henderson, E. F. 2018. "Feminist conference time: Aiming (not) to have been there." Chapter XX in Y. Taylor and K. Lahad (Eds.) Feeling Academic in the Neoliberal University: Feminist Flights, Fights and Failures (pp. 33-60). London: Palgrave.

Hickson, M., III. 2006. "Raising the question \#4: Why bother attending conferences?" Communication Education, 55(4): 464-468. doi:10.1080/03634520600917632.

Hinsley, A., Sutherland, W. and Johnston, A. 2017. "Men ask more questions than women at a scientific conference". PLOS ONE, 12(10): 1-14. doi: doi:10.1371/journal.pone.0185534.

Hochschild, A. 1983/2003. The managed heart: Commercialization of human feeling. Berkeley: University of California Press.

Hodge, N. 2014. "Unruly bodies at conference”. Disability and Society, 29(4): 655658. doi:10.1080/09687599.2014.894749.

Isbell, L. A., Young, T. P. and Harcourt, A. H. 2012. "Stag parties linger: Continued gender bias in a female rich scientific discipline". PLOS ONE, 7(11): 1-4. doi:10.1371/journal.pone.0049682.

Jacobs, N., and McFarlane, A. 2005. "Conferences as learning communities: Some early lessons in using 'back-channel' technologies at an academic conference distributed intelligence or divided attention?" Journal of Computer Assisted Learning, 21: 317-329. doi:10.1111/j.1365-2729.2005.00142.x.

Jackson, L. 2017. “The smiling philosopher: Emotional labor, gender, and harassment in conference spaces", Educational Philosophy and Theory. [online ahead of press]. doi:10.1080/00131857.2017.1343112. 
Jones, T. M., Fanson, K. V., Lanfear, R., Symonds, M. R. E. and Higgie, M. 2014. "Gender differences in conference presentations: A consequence of selfselection?" PeerJ, 1-5. doi:10.7717/peerj.627.

King, L., MacKenzie, L., Tadaki, M., Cannon, S., McFarlane, K., Reid, D., and Koppes, M. 2018. "Diversity in geoscience: Participation, behaviour, and the division of scientific labour at a Canadian geoscience conference". FACETS 3, 415-440. doi:10.1139/facets-2017-0111.

Lawn, M. 2015. "Working as a European, working as an EERA member". European Educational Research Journal, 14(I): 26-29. doi:10.1177/1474904114565163.

Lewis, G. 2013. "Experiencing intersectionality and feminist displacements". Signs, 38(4): 869-892.

Lynch, K. 2010. "Carelessness: A hidden doxa of higher education". Arts and Humanities in Higher Education, 9(1): 160-162. doi:10.1177/1474022209350104.

Mair, J. and Frew, E. 2018. "Academic conferences: a female duo-ethnography”. Current Issues in Tourism, 21(18): 2152-2172. doi:10.1080/13683500.2016.1248909.

Manathunga, C. 2007. “'Unhomely’ academic developer identities: more post-colonial explorations". International Journal for Academic Development, 12(1): 25-34. doi:10.1080/13601440701217287.

Mantai, L. 2017. "Feeling like a researcher: experiences of early doctoral students in Australia". Studies in Higher Education, 42(4): 636-650. doi:10.1080/03075079.2015.1067603.

Pereira, M. 2012. “'Feminist theory is proper knowledge, but ...': The status of feminist scholarship in the academy". Feminist Theory, 13(3): 283-303. doi:10.1177/1464700112456005.

Peseta, T., Barrie, S. and McLean, J. 2017 "Academic life in the measured university: pleasures, paradoxes and politics". Higher Education Research and Development, 36(3): 453-457. doi:10.1080/07294360.2017.1293909.

Polkinghorne, D.E. 1995. "Narrative configuration in qualitative analysis". Qualitative Studies in Education, 8(1): 5-23. doi:10.1080/0951839950080103.

Rafnsdottir, G.L. and Heijstra, T.M. 2013. "Balancing work-family life in academia: the power of time". Gender, Work and Organization, 20(3): 283-296. doi:10.1111/j.1468-0432.2011.00571.x. 
Saul, J. 1992. "Planning a women's studies conference". Feminist Teacher, 7(1): 22-25.

Schostak, J. 2006. Interviewing and Representation in Qualitative Research.

Maidenhead: Open University Press/McGraw Hill.

Skelton, A. 1997. “Conferences, conferences, conferences?” Teaching in Higher Education, 2(1): 69-72. doi:10.1080/1356251970020106.

Smith, J. 2010. "Academic Identities for the twenty-first century". Teaching in Higher Education, 15(6): 721-727. doi:10.1080/13562517.2010.522341.

Smith, J., Rattray, J., Peseta, T. and Loads, D. 2016. Identity work in the contemporary university: Exploring an uneasy profession. Rotterdam: Sense Publishers.

Squire, C. 2008. "Experience-centred and culturally-oriented approaches to narrative". Chapter XX in Andrews, M., Squire, C. and Tamboukou, M. (Eds), Doing Narrative Research. London: Sage Publications.

Stadlen, N. 2004. What Mothers Do: Especially When it Looks Like Nothing. London: Hachette.

Stanley, J. 1995. "Pain(t) for healing: The academic conference and the classed/embodied self." Chapter 12 in V. Walsh and L. Morely (Eds.), Feminist academics: Creative agents for change (pp. 169-182). London: Taylor and Francis.

Toffoletti, K. and Starr, K. 2016. "Women academics and work-life balance: Gendered discourses of work and care". Gender, Work and Organization, 23(5): 489-504. doi:10.1111/gwao.12133.

Walford, G. 2011. "The Oxford ethnography conference: A place in history?" Ethnography and Education, 6(2): 133-145.

doi:10.1080/17457823.2011.587354. 